Research Article

\title{
The Correlation between Psychosocial Stress and Prematurity
}

\section{Hubungan Derajat Stres Psikososial Ibu terhadap Kejadian Persalinan Kurang Bulan}

\author{
Renny Aditya, Jusuf S Effendi, Teddy Hidayat, Tita H Madjid \\ Department of Obstetrics and Gynecology \\ Faculty of Medicine University of Padjadjadran/ \\ Dr. Hasan Sadikin Hospital \\ Bandung
}

\begin{abstract}
Objective: This study was aimed to analyze the relationship between the level of psychosocial stress on preterm birth and term birth.

Methods: This was a cross-sectional study, with 45 patients experiencing preterm birth and at term birth, who met the inclusion and exclusion criterias in Obstetrics and Gynecology Department of Dr. Hasan Sadikin Hospital and other hospital nearby.

Result: The level of psychosocial stress on preterm birth was severe $64.4 \%$, moderate $14 \%$ and mild $2 \%$. The comparison between the group resulted in $\mathrm{p}<0.001$ using chi-square test with confidence interval $95 \%$ and correlation coefficient was phi $=0.811$. The specific psychosocial stressor were problem with in laws $(\mathrm{p}=0.001)$, problem with husband $(\mathrm{p}=0.003)$, foreclosure on a mortgage or loan $(\mathrm{p}=0.001)$, change in residence $(\mathrm{p}=0.001)$, major change in living conditions (building a new home, remodeling) $(\mathrm{p}=0.001)$, no monetary possession $(p=0.001)$, major change in financial state $(p=0.004)$, environment vulnerability $(\mathrm{p}=0.035)$, and being dismissal from work $(\mathrm{p}=0.014)$.
\end{abstract}

Conclusion: The relationship between psychosocial stress and preterm birth was significant. The stressor included problem with in laws foreclosure on a mortgage or loan, change in residence, major change in living conditions (building a new home, remodeling, no monetary possesion, major change in financial state, environment vulnerability, and dismissal from work.

[Indones J Obstet Gynecol 2012; 36-2: 55-60]

Keywords: preterm birth, psychosocial stress

\begin{abstract}
Abstrak
Tujuan: Penelitian ini dilakukan untuk menganalisis hubungan kejadian stres psikososial ibu pada persalinan kurang bulan dan persalinan cukup bulan dan menganalisis hubungan antara derajat beratnya stres psikososial ibu terhadap kejadian persalinan kurang bulan.

Metode: Penelitian dilakukan secara potong silang (cross-sectional study) terhadap masing-masing 45 subjek pada persalinan cukup bulan dan persalinan kurang bulan yang memenuhi syarat penelitian di Bagian Obstetri dan Ginekologi FKUP/RS Dr. Hasan Sadikin Bandung beserta rumah sakit jejaring lainnya yang memenuhi kriteria inklusi, kriteria eksklusi.
\end{abstract}

Hasil: Hasil uji chi kuadrat perbedaan antara kedua kelompok tersebut adalah $p<0,001$ dengan taraf kepercayaan 95\% dan koefisien korelasi phi yang bermakna yaitu phi=0,811. Stres psikososial pada persalinan kurang bulan ditemukan derajat berat sebanyak $64,4 \%$, sedang $14 \%$, ringan $2 \%$. Jenis stresor berupa konflik dengan mertua, menantu atau ipar (nilai $p=0,001$ ), konflik dengan suami (nilai $p=0,003$ ), ditagih hutang atau mempunyai hutang (nilai $p=0,001$ ), pindah tempat tinggal (nilai $p=0,001$ ), tidak mempunyai uang (nilai $p=0,001$ ), perubahan dalam penghasilan (nilai $p=0,004$ ), pindah tempat tinggal (nilai $p=0,001$ ), menghadapi kerawanan lingkungan (nilai $p=0,035$ ), kehilangan pekerjaan (nilai $p=0,014$ ).

Kesimpulan: Dari hasil penelitian kali ini dapat disimpulkan bahwa terdapat perbedaan dan hubungan antara stres psikososial dan persalinan kurang bulan dengan stresor berupa konflik dengan mertua, menantu atau ipar, konflik dengan suami, ditagih hutang atau mempunyai hutang, pindah tempat tinggal, tidak mempunyai uang, perubahan dalam penghasilan, pindah tempat tinggal, menghadapi kerawanan lingkungan, kehilangan pekerjaan.

[Maj Obstet Ginekol Indones 2012; 36-2: 55-60]

Kata kunci: persalinan kurang bulan, stres psikososial

Correspondence: Renny Aditya. Department of Obstetrics and Gynecology, Faculty of Medicine University of Padjadjaran/ Dr. Hasan Sadikin Hospital, Bandung. Telephone: 087825007575, Email: rennyaditya@gmail.com

\section{INTRODUCTION}

Low birth weight (LBW), prematurity and intrauterine growth retardation (IUGR) remain to be the leading causes of perinatal morbidity, mortality, neurodevelopmental impairments and disabilities among newborn babies. ${ }^{1-3}$ The belief that a mother's psychological status may affect her fetus has been common in every society since ancient times. Animal studies have demonstrated that exposing ani- mals to stressors during pregnancy is associated with lower birth of fetal weights. Indonesia has a poor record when it comes to premature births. ${ }^{4,5}$ The 2010 World Fact Book released by WHO ranks Indonesia on the fourth place for the highest perinatal mortality rate, with 28.9 deaths per 1,000 births. Worldwide, of 15.5 million babies are born preterm every year, at least a million of whom die 
soon after. ${ }^{6-8}$ In its Basic Health Research in 2007, the Indonesian Health Ministry said around 400, 000 babies were born preterm in Indonesia, or about 10 percent of total births. According to the 2009 study by the Indonesian Hospitals Association, the mortality rate among premature babies in the country is 30 percent, which means 120,000 babies born preterm die every year. ${ }^{7,8}$ A direct relationship between maternal psychological stress distress and LBW, prematurity and IUGR may be related to the release of catecholamines, which results in placental hypoperfusion and consequent restriction of oxygen and nutrients to the foetus, leading to foetal growth impairment or precipitation of preterm delivery. ${ }^{9,10}$

\section{METHODS}

This study was designed as a cross-sectional study, with 45 subjects of preterm birth and at term birth that met inclusion and exclusion criterias in Obstetrics and Gynecology Department of Dr. Hasan Sadikin Hospital and other hospital besides it. The subjects divided into two groups, preterm delivery group and at term delivery group.

The inclusion criteria were a live single birth, intact amnion, mother's age $\geq 18$ years old, no history of smoking, alcohol consumption and drug abuse, normal index body mass $\left(18-25 \mathrm{~kg} / \mathrm{m}^{2}\right)$. No history of bleeding on trimester II and III, uterine abnormality (from physical diagnosis and USG), history of renal diseases, heart diseases, hypertension, diabetes mellitus, infection and other systemic diseases, no history of mental disorders. The preterm delivery was selected among patients with gestational age of 28-36 (from last menstrual periods). For term delivery, the gestational age was $\geq 37$ weeks from last menstrual periods.

The exclusion criteria were congenital abnormality, stilbirth and twin pregnancy. Subjects were recruited by consecutive sampling.

Sample size was calculated based on the $95 \%$ confidential interval and power test $90 \%$. Data were analyzed using SPSS 18 for windows. The chi squares test was performed for nominal variables.

\section{RESULTS}

Table 1. The Characteristic of Subject in Preterm and Term delivery

\begin{tabular}{|c|c|c|c|c|c|}
\hline \multirow{3}{*}{ Characteristic } & \multicolumn{4}{|c|}{ Type of Delivery } & \multirow{3}{*}{$\left.\mathbf{p}^{*}\right)$} \\
\hline & \multicolumn{2}{|c|}{ Preterm } & \multicolumn{2}{|c|}{ Term } & \\
\hline & $(n=45)$ & $\%$ & $(n=45)$ & $\%$ & \\
\hline \multicolumn{6}{|l|}{ Age } \\
\hline$<25$ & 15 & 33.3 & 7 & 15.6 & 0.053 \\
\hline $25-29$ & 13 & 28.9 & 8 & 17.8 & \\
\hline $30-34$ & 14 & 31.1 & 25 & 55.6 & \\
\hline $35-39$ & 3 & 6.7 & 5 & 11.1 & \\
\hline \multicolumn{6}{|l|}{ Parity } \\
\hline 1 & 5 & 11.1 & 12 & 26.6 & 0.070 \\
\hline 2 & 11 & 22.2 & 14 & 44.4 & \\
\hline 3 & 20 & 44.4 & 10 & 22.2 & \\
\hline$>3$ & 9 & 20 & 9 & 20 & \\
\hline \multicolumn{6}{|l|}{ Education } \\
\hline Elementary school & 16 & 35.6 & 19 & 42.2 & 0.562 \\
\hline Junior high school & 23 & 51.1 & 18 & 40.0 & \\
\hline Senior high school & 6 & 13.3 & 8 & 17.8 & \\
\hline \multicolumn{6}{|l|}{ Marital status } \\
\hline Married & 36 & 80.0 & 37 & 82.2 & 0.455 \\
\hline Not married & 0 & 0 & 2 & 4.4 & \\
\hline Divorce & 6 & 13.3 & 4 & 8.9 & \\
\hline Widow & 3 & 6.7 & 2 & 4.4 & \\
\hline \multicolumn{6}{|l|}{ Husband Job } \\
\hline Labor & 34 & 75 & 27 & 60 & 0.546 \\
\hline Merchant & 5 & 11.1 & 8 & 17.7 & \\
\hline Unemplyoment & 6 & 13.3 & 10 & 22.2 & \\
\hline
\end{tabular}

Table 2. Psychosocial stress in Preterm and Term delivery

\begin{tabular}{|c|c|c|c|c|c|}
\hline \multirow{3}{*}{$\begin{array}{l}\text { Psychosocial } \\
\text { stress }\end{array}$} & \multicolumn{4}{|c|}{ Type of Delivery } & \multirow{3}{*}{$\left.\mathbf{p}^{*}\right)$} \\
\hline & \multicolumn{2}{|c|}{ Preterm } & \multicolumn{2}{|c|}{ Term } & \\
\hline & $(n=45)$ & $\%$ & $(n=45)$ & $\%$ & \\
\hline None & 0 & 0 & 6 & 13.3 & $<0.001$ \\
\hline Mild & 2 & 4.4 & 30 & 66.7 & \\
\hline Moderate & 14 & 31.1 & 9 & 20 & \\
\hline Severe & 29 & 64.4 & 0 & 0 & \\
\hline
\end{tabular}


Table 3. Major life events as psychosocial stressors in preterm and term delivery

\begin{tabular}{|c|c|c|c|}
\hline Major life events & $\begin{array}{c}\text { Preterm } \\
\text { delivery } \\
\text { (\%) }\end{array}$ & $\begin{array}{c}\text { Term } \\
\text { delivery } \\
\text { (\%) }\end{array}$ & $\left.\mathbf{p}^{*}\right)$ \\
\hline Problems with family & - & 24.4 & 0.001 \\
\hline $\begin{array}{l}\text { Foreclosure on mort- } \\
\text { gage or loan }\end{array}$ & 4.4 & 40 & 0.001 \\
\hline Change in residences & 8.9 & 42.2 & 0.001 \\
\hline Problem in financial & 13.3 & 46.7 & 0.001 \\
\hline Problems with husband & 20 & - & 0.003 \\
\hline $\begin{array}{l}\text { Major change in financial } \\
\text { problems }\end{array}$ & 13.3 & 42.2 & 0.004 \\
\hline Problems in family health & - & 15.6 & 0.012 \\
\hline Has to sell worthy tools & - & 15.6 & 0.012 \\
\hline Being fired at work & 4.4 & 24.4 & 0.014 \\
\hline $\begin{array}{l}\text { Environment vulnera- } \\
\text { bility }\end{array}$ & 17.8 & 40 & 0.035 \\
\hline
\end{tabular}

The result using chi-square test was $\mathrm{p}<0.001$ with confidence interval $95 \%$ and the correlation coefficient was phi $=0.811$. The level of psychosocial stress on preterm birth was severe $64.4 \%$, moderate $14 \%$ and mild $2 \%$. The specific psychosocial stressor were problem with in laws $(\mathrm{p}=$ $0.001)$, problem with husband $(\mathrm{p}=0.003)$, foreclosure on a mortgage or loan $(\mathrm{p}=0.001)$, change in residence $(p=0.001)$, major change in living conditions (building a new home, remodeling) ( $\mathrm{p}=$ $0.001)$, no monetary possesion $(p=0.001)$, major change in financial state $(\mathrm{p}=0.004)$, environment vulnerability $(p=0.035)$, and dismissal from work $(\mathrm{p}=0.014)$.

\section{DISCUSSION}

Low birth weight (LBW), prematurity and intrauterine growth retardation (IUGR) remain the leading causes of perinatal morbidity, mortality, neurodevelopmental impairments and disabilities among newborn babies. Preterm birth is the leading cause of neonatal mortality and a substantial portion of all birth-related short and long-term morbidity. 1,2 Spontaneous preterm labor is responsible for more than half of preterm births.

Although there are many maternal characteristics associated with preterm birth, the etiology in most cases is not clear. Most efforts to prevent preterm labor have not proven to be effective and frustratingly, most efforts at arresting preterm labor once started were mostly failed. ${ }^{3,4}$ The most important components of management, therefore, are aimed at preventing neonatal complications through the use of corticosteroids and antibiotics to prevent group B streptococcal neonatal sepsis, and avoiding traumatic deliveries.

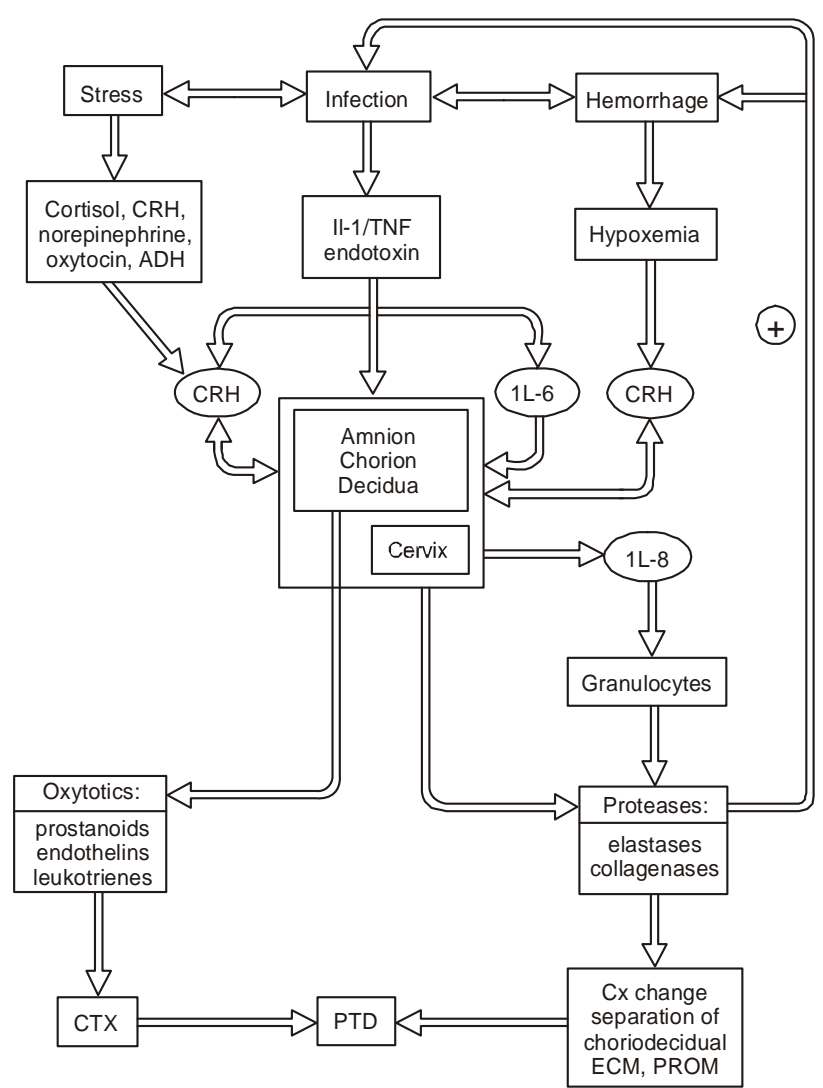

Figure 1. Etiology in preterm delivery.

ADH (anti diuretic hormone), IL (interleukin), TNF (tumor necrosis factor), CTX (contractions), PTD (preterm delivery), Cx (cervix), ECM (extracellular matrix), PROM (premature rupture of membranes). ${ }^{1,2}$

As shown in Figure 1, infection is a frequent and important mechanism of disease in preterm delivery. Indeed, it is the only pathologic process for which an unequivocal causal link with preterm parturition has been established. ${ }^{1,2}$

Vaginal bleeding in the first or second trimester is a risk factor for preterm birth. ${ }^{3,4}$ Vaginal bleeding in the first trimester alone is associated with an adjusted risk ratio of 2 (95\% CI, 1.6 to 2.5) for preterm delivery. If vaginal bleeding is present in more than one trimester, the odds ratio for preterm PROM is 7.4 (95\% CI, 2.2 to 25.6). Therefore, a disorder of uterine hemostasis that manifests clinically as bleeding places the patient at risk for preterm birth. 
Delivery in a medical center with an experienced resuscitation team and the availability of a newborn intensive care unit will ensure the best possible neonatal outcomes. In the United States, the preterm delivery rate is approximately $11 \%$, whereas in Europe it varies between 5\% and 7\%.11

In spite of advances in obstetric care, the rate of prematurity has not decreased over the past 40 years. ${ }^{7,11}$ In fact, in most industrialized countries, it has increased slightly. Prematurity remains a leading cause of neonatal morbidity and mortality in developed countries, accounting for $60-80 \%$ of deaths of infants without congenital anomalies. $3,7,8$

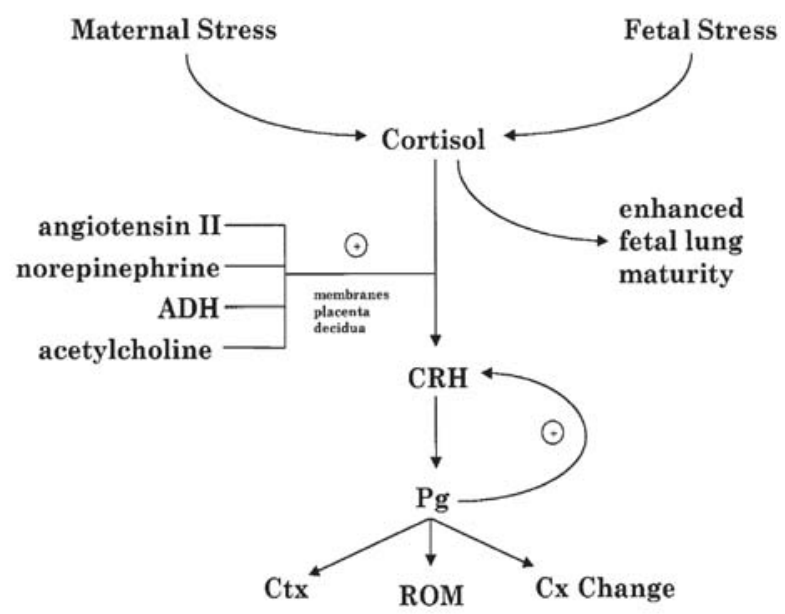

Figure 2. Stress mechanism in preterm delivery. ADH (anti diuretic hormone), IL (interleukin), TNF (tumor necrosis factor), CTX (contractions), PTD (preterm delivery), Cx (cervix), ECM (extracellular matrix), PROM (premature rupture of membranes). ${ }^{11}$

As the risk of neonatal morbidity and mortality near term is low, greater attention is now being focused on early preterm birth (32 weeks' gestation). Although births in this gestational age group represent $1 \%$ to $2 \%$ of all deliveries, they account for nearly $50 \%$ of all long term neurological morbidity and about $60 \%$ of perinatal mortality.8,9

The belief that a mother's psychological status may affect her foetus has been common in every society, since ancient times. Animal studies have demonstrated that exposing animals to stressors during pregnancy is associated with lower birth or fetal weight. A direct relationship between maternal psychological stress distress and LBW, prematurity and IUGR may be related to the release of catecholamine, which results in placental hypo perfusion and consequent restriction of oxygen and nutrients to the fetus, leading to fetal growth im- pairment and/or precipitation of preterm delivery. ${ }^{1,13}$

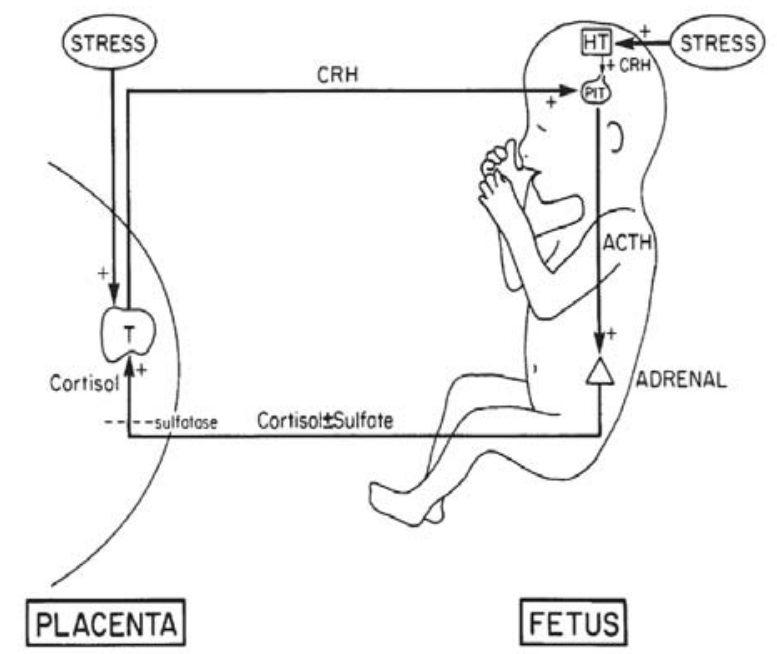

Figure 3. Fetoplacental $\mathrm{CRH}$ and glucocorticoid mechanism. ${ }^{15}$

Figure 3 also shown how maternal stress might affect development of the fetal brain and HPA-axis activity. ${ }^{8}$ Maternal cortisol that has escaped from inactivation by $11 \mathrm{~h}-\mathrm{HSD}$ in the placenta may participate in the feed-forward loop between the placenta and the fetal pituitary-adrenal axis. Overproduction and hypersecretion of fetal cortisol thus may arise from maternal cortisol in the fetal compartment and/or from pCRH secretion. ${ }^{15}$ Increased fetal cortisol (of maternal or fetal origin) may inhibit growth and differentiation of the developing nervous system, damage the brain, and have a programming or organizing effect on the fetal neuroendocrine system resulting in the permanent disorders mentioned earlier. ${ }^{9,10}$

Prenatal maternal stress and anxiety may be responsible for an important proportion of the other (unexplained) cases. This appears from recent well-performed studies that took into account medical and obstetric histories, life style (smoking and drinking behaviour), socioeconomic status, and the course of pregnancy and delivery. These studies have demonstrated that exposure to prenatal stress not only affects physical development of the infants (birth weight, head size, and structural malformations), but also their functional development, evidenced by poor psychomotor performance and more difficult behaviour during the first 10 years of life. Whether these problems will be longlasting and permanent and will eventually lead to psychopathology has to be revealed by con- 
tinuation of the existing follow-up studies and by other independent studies. ${ }^{12,13}$

The relationship between stressful experiences during pregnancy and an increased risk of preterm delivery has been a consistent finding of independent studies for several decades. It has been suggested that preterm uterine activity and shortened length of pregnancy result from stress during the third trimester. Remarkably, serum concentrations of placental CRH are already raised at 15-20 weeks of pregnancy in women who deliver preterm. The question of how signals of maternal stress may reach the fetus has not been dealt with so far. It seems most logic that this occurs through (stress) hormones. Three mechanisms may be distinguished, which may operate simultaneously and may amplify each other's effects. The possible mechanisms involve: reduction in blood flow to the uterus and fetus at increased levels of maternal stress; trans placental transport of maternal hormones; stress-induced release of placental CRH to the intrauterine environment. 13,14

Higher amounts of a stress-related corticosteroid or opiate increasing the vulnerability to infectious diseases (particularly chorioamnionitis), a higher degree of neuromuscular reactivity and increases in the secretion of oxytocin are other important direct mediators. ${ }^{8,10}$

Table 2 showed that from term delivery, mild psychosocial stress were 30 (66.7\%), no psychosocial stress were $6(13.3 \%)$ and moderate psychosocial stress were 9 (20\%). From preterm delivery, we found that severe psychosocial stress were 29 (64.4\%), moderate psychosocial stress 14 (31.3\%) and mild psychosocial stress were 2 (4.4\%). From chi square results showed significant psychosocial stress differences between preterm and term delivery (95\%; $p<0.05$; coefficient phi: 0.811 ). The maternal psychosocial stress was assed using Holmes and Rahe questionnaire, a screening instrument design for use in general population sampling.

The score indicates the severity of psychosocial disturbances in continuum which situation during the last month had been appraised as stressful life events. The content and concurrent validity of the questionnaire have been tested in Indonesia on 2010 and all around the world. ${ }^{16}$

On 2010 Holmes and Rahe stress scale had been re-validated on Occupational Medicine, and still be- ing relevant to determine the severity of stress which can be the etiology for medical disorders. The psychometric stress scale showed high correlation between subgrup of questionnaire with coefficient concordance $0.477(\mathrm{p}<0.0005)$ and retest-reliability can show that more the severity of psychosocial stress will predict more medical disturbances. ${ }^{16}$

The differences between the group was $\mathrm{p}<$ 0.001 using chi-square test with confidence interval $95 \%$ and correlation coefficient was phi $=$ 0.811 . The level of psychosocial stress on preterm birth was severe $64.4 \%$, moderate $14 \%$ and mild $2 \%$. The specific psychosocial stressor were problem with in laws $(\mathrm{p}=0.001)$, problem with husband $(\mathrm{p}=0.003)$, foreclosure on a mortgage or loan $(p=0.001)$, change in residence $(p=0.001)$, major change in living conditions (building a new home, remodeling) ( $\mathrm{p}=0.001)$, no monetary possesion $(p=0.001)$, major change in financial state $(\mathrm{p}=0.004)$, environment vulnerability $(\mathrm{p}=0.035)$, and dismissal from work $(\mathrm{p}=0.014)$.

\section{CONCLUSION}

The differences and relation between psychosocial stress and preterm birth was significant. The stressor were problem with in laws foreclosure on a mortgage or loan, change in residence, major change in living conditions (building a new home, remodeling), no monetary possesion, major change in financial state, environment vulnerability, and dismissal from works.

\section{REFERENCES}

1. Cunningham FG, Gant NF, Leveno KJ, Gillstrap LC, Hauth JC, Wenstrom KT. Williams Obstetrics. 23 ${ }^{\text {th }}$ ed. New York: McGraw-Hill; 2010

2. Walkinshaw SA. Preterm labour and delivery of the preterm infant. In: Chamberlain G, Steer P, editor. Turnbull's Obstetrics. $3^{\text {th }}$ ed. London: Churchill Livingstone; 2002: 493-514

3. Krisnadi SR, Effendi JS, Pribadi A. Prematuritas. Bandung: PT. Refika Aditama; 2009

4. Goldenberg RL, Rouse DJ. Prevention of premature birth. London: McGraw-Hill; 2008; 339(5): 313-20

5. Gorsuch RL, Key MK. Abnormalities of pregnancy as a function of anxiety and life stress. Psychosom Med. 2004; 36(4): 352-62

6. Moutquin JM. Socio-economic and psychosocial factors in the management and prevention of preterm labour. $\mathrm{Br} \mathrm{J}$ Obstet Gynaecol 2010; 20: 5660

7. Borders AE, Grobman WA, Amsden LB. Chronic stress and low birth weight neonates in a low-income population of women. Obstet Gynecol. 2007; 109: 331-8 
8. Sable MR, Wilkinson DS. Impact of perceived stress, major life events and pregnancy attitudes on low birth weight. Fam Plann Perspect. 2000; 32(6): 288-94

9. Dunkel-Schetter C, Scrimshaw SC. Prenatal-maternal stress and prematurity: a prospective study of socioeconomically disadvantaged women. Health Psychol. 2007; 11(1): 32-40

10. Rondó PH, Ferreira RF, Nogueira F. Maternal psychological stress and distress as predictors of low birth weight, prematurity and intrauterine growth retardation. Eur J Clin Nutr. 2008; 57(2): 266-72

11. Copper RL, Goldenberg RL, Das A. The preterm prediction study: Maternal stress associated with spontaneous preterm birth at less than thirty-five weeks' gestation. National Institute of Child Health and Human Development Maternal-Fetal Medicine Units Network. Am J Obstet Gynecol. 2007; 175(5): 1286-92
12. Fink G. Pregnancy and stress. In : Cox T, De Kloet RE, Swansson L, editor. Encyclopedia of stress. New York: Academic Press; 2010: 455-527

13. Contrada RJ, Baum A. The handbook of stress science: biology, psychology, and health. New York: Springer Press; 2000: $80-120$

14. Baer L, Blais MA. Handbook of clinical rating scales and assessment in psychiatry and mental health. New York: Humana Press; 2010: 230-50

15. Ian McDowell. Measuring health a guide to rating scales and questionnaires. $3^{\text {rd }}$ Ed. New York: Oxford Univ Press; 2006: 40-67

16. Dunkel S, Roesch SC, Grace W, Hobel CL. Modelling the types and timing of stress in pregnancy. Am J Psycho Ass. 2009; 17: $87-102$ 